\title{
Zefrizal Nurdin
}

Bagian Hukum Perdata Fakultas Hukum Universitas Andalas, Padang.

Kampus Limau Manis, Padang, Sumatera Barat 25163. Email: zefrizalnurdindyahoo.com

\section{DILEMA PEMANFAATAN TANAH ULAYAT UNTUK INVESTASI DI SUMATERA BARAT PADA NORMA DAN IMPLEMENTASI}

\section{ABSTRACT}

The Communal Right to Land (Hak Ulayat), both as the economic source and communal identity, should be empowered and be protected. This research studies the regulation of the utilization of Tanah Ulayat for the interest of investment and finds the root of its conflict in West Sumatera. The result of the research concludes that there is no both horizontal and vertical synchronization in regulating of Tanah Ulayat. The regulationsthat have been enacted by DPRD and governor of West Sumatera are not in line with the Adat and Custom of Adat Community. Those regulations are also far from an ideal regulation and Syariah (Islamic Law), while the root of the conflict is the inconsistence between the regulation ofTanah Ulayat and its implementation which ignore the contract.

Key Words: utilization, tanah ulayat, investment.

\section{ABSTRAK}

Tanah ulayat sebagai sumber ekonomi dan juga identitas persekutuan perlu diberdayakan dan dilindungi. Penelitian ini mengkaji bagaimana pengaturan pemanfaatan tanah ulayat untuk kepentingan investasi serta mencari akar konfliknya di Sumatera Barat. Tehnik pendekatan yang digunakan adalah gabungan antara yuridis normatif dengan yuridis empiris. Hasil penelitian menemukan terjadinya dissinkronisasi horizontal dan vertikal dalam pengaturan tanah ulayat. Aturan yang disahkan oleh DPRD dan Peraturan Gubernur Sumatera Barat juga tidak sejalan dengan 
aturan adat dan kebiasaan masyarakat hukum adat. Aturan tersebut juga jauh dari suatu aturan yang ideal dan syariah (hukum Islam), sementara akar konflik dipicu oleh ketimpangan norma dan implementasi yang mengabaikan kontrak.

Kata kunci : pemanfaatan, tanah ulayat, investasi.

\section{PENDAHULUAN}

Tanah punya peran penting dalam kehidupan orang, tidak hanya untuk memenuhi kebutuhan aspek ekonomi, tapi juga aspek sosial, budaya dan lainnya. Diluar aspek ekonomi misalnya, dalam masyarakat adat keaslian seseorang pada ranah ia berdiam lazim pula diukur dengan kepemilikan tanah yang ia punyai. Peran strategis tanah menurut Suroyo Wignyodipuro adalah sebagai harta kekayaan yang keadaannya bersifat tetap/abadi dan fakta hubungan antara orang/persekutuan dengan tanah (Soeroyo Wignyodipuro, (1993: 197). Terjadinya penjajahan atas suatu negara, pada hakikatnya bertujuan merebut aset tersebut. Tak hanya kelompok besar sebagai suatu negara, kelompok kecil bahkan individu selalu muncul keinginan kuat untuk memperoleh tanah yang terkadang tak peduli cara.

Sejarah telah membuktikan, masuknya pemerintah kolonial ke Indonesia tak lain berawal dari perebutan tanah-tanah di nusantara yang umumnya produktif, sehingga mampu mensuplai kebutuhan komoditi Eropa. Pada saat itu muncullah tuan-tuan tanah dari kalangan bangsa Eropa dengan mendesak hak-hak atas tanah Bumiputra.

Alur strategi kebijakan kolonial ialah bagaimana cara yang lebih efektif untuk memperoleh tanah (dan tenaga kerja) dalam jumlah yang diperlukan guna meneruskan upaya agar bumi Hindia Belanda, khususnya pulau Jawa dapat tetap menjadi daerah usaha agrikultural yang menguntungkan dan saldo plus (batig slot) dalam kas negeri Belanda tetap dapat dijamin (Soetandyao Wignjosoebroto, 1995: 90).

Melalui "domeinverklaring” yang dimuat dalam Pasal 1 Agrarische Besluit (AB. No. 118 Tahun 1870), pemerintah kolonial mengklaim seluruh tanah di Hindia Belanda, baik hak atas tanah perseorangan ataupun persekutuan hukum adat sebagai tanah milik negara, sejauh tak dapat dibuktikan eigendomnya. Terhadap hak ulayat yang pada umumnya saat itu masih terbengkalai, atau dibiarkan tak tergarap karena memang direncanakan untuk aset perekonomian bagi keturunan selanjutnya dari anggota persekutuan yang lambat laun pasti akan berkembang dan membutuhkan lahan untuk pertanian serta pembukaan kampung baru, jauh lebih mudah untuk diklaim sebagai eigendom negara bagi pemerintah Belanda.

Setelah 15 tahun merdeka, Pemerintah mengesahkan Undang Undang Nomor 5 Tahun 1960 tentang Peraturan Dasar Pokok-pokok Agraria dan melalui ketentuan Pasal 3 hak ulayat itu diakui eksistensinya sepanjang kenyataannya masih ada. Selama era Orba tidak ditetapkan satu pengaturanpun yang secara khusus mengatur tentang Hak Ulayat, kecuali sekadar dapat bersentuhan dengan hak ulayat, seperti Permendagri No. 15 Tahun 1975 tentang Ketentuanketentuan mengenai Tata cara Pembebasan tanah, yang dapat saja terjadi pada tanah 


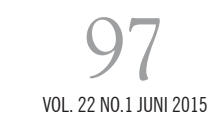

ulayat.Pemerintahan reformasi mencoba melangkah lebih maju, dengan telahmenetapkan 3 aturan penting terkait hak ulayat, yakni Peraturan Menteri Negara Agraria/Kepala Badan Pertanahan Nasional Nomor 5 Tahun 1999 Tentang Pedoman Penyelesaian Masalah Hak Ulayat, Permendagri Nomor 52 tahun 2014TentangPedomanpengakuandanperlindunganmasyarakathukumadat, disusul Peraturan Menteri Agraria dan Tata Ruang/ Kepala Badan Pertanahan Nasional No. 9 Tahun 2015 tentang Tata Cara Penetapan Hak Komunal atas Tanah Masyarakat Hukum Adat dan Masyarakat yang Berada dalam Kawasan Tertentu dan sekaligus mencabut berlakunya Peraturan Menteri Negara Agraria/Kepala Badan Pertanahan Nasional Nomor 5 Tahun 1999 diatas. Melalui Pasal 18 B (2) UUD setelah amandemen, hak ulayat diakui sebagai hak konstitusional masyarakat hukum adat dan kemudian dipandang sebagai aset desa oleh Undang-UndangNomor 6Tahun2014. Terdapat beragam peraturan lainnya terkait tanah ulayat, antara lain Undang -Undang No. 25 Tahun 2007 Tentang Penanaman Modaldan Undang-Undang Nomor 39 Tahun 2014 Tentang Perkebunan. Seperangkat aturan yang dikeluarkan itu diharap dapat mengundang minat para investor dalam berinvestasi.

Merespon kewenangan lebih luas pada otonomi daerah, sekaligus untuk memancing investasi, Pemerintah Provinsi Sumatera Barat mengesahkan Perda PropinsiNo.6Tahun 2008 Tentang TanahUlayat dan Pemanfatannya dan PeraturanGubernur (Pergub) SumateraBarat Nomor21 Tahun 2012 Tentang Pedoman Dan Tata Cara Pemanfatan Tanah Ulayat Untuk Penanaman Modal.Sejak, semula tujuan dikeluarkan Perda dan Pergub di atas adalah untuk dijadikan sebagai acuan oleh pihak terkaitdalam penanaman modal, sehingga dapat menimbulkan kepastian hukum dalam pemanfaatan tanah ulayat oleh investor di Sumatera Barat dan sekaligus menekan potensi konflik. Ternyata konflik tak berhenti tumbuh. Menurut Nurul Firmansyah dari LSM Qbar;

Sejak tahun 2005di SumateraBarattelahterjadi218konfliktanah ulayat (hak adat) dengan luas 119.299 hektar yang melibatkan perkebunan sawit. Rata-rata ada 10-20 konflik tanah setiap tahunnya di Sumbar, dengan peningkatan sekitar 30\%pertahun. ${ }^{3}$ Arfi Bambani Amri mengutip Sukardi Bendang (koordinator SPI Sumbar) menyatakan bahwa jumlah sesungguhnya bisa lebih besar dari itu, karena diantaranya tidak menyebar.

Desentralisasilegislasikepadadaerah,mengakibatkan lahirnya berbagai produk hukum di daerah yang bila dilakukan tidak hati-hati dapat menimbulkan beragamproblemhukumdidaerah dan ujung- ujungnya akan tetap menyentuh pusat. Khusus dalam pengaturan sumber dayaagraria berupa tanah ulayat dan asetn yadi SumateraB arat problem yuridis yang essensial berdasar identifikasi penulis adalah: Pertama, desentralisasi legislasi, akan menimbulkan pluralisme hukumyang bisa memicu dissinkronisasi. Tapi, manakala antara perundangan-undangan yang lebih tinggi saja, baik selevel atau tidak justru mengalami dissinkronisasi (Kurnia Warman, 2010: 4), lantas bagaimana Badan legislasi daerahProvinsi Sumatera Barat telah dan harusberbuat? Ibarat suatu orkestra yang tidak padu, irama manakah yang harusdiikutipenari?Kekacauan bakalkianmenjadi, bila sang penari tak pula menguasai tarian, karena dipilih berdasar selera massa yang tingkat kejeliannya dalam memilih diragukan. 
Kedua, filosofi adat Minangkabau "adat basandi syarak,syarak basandi Kitabullah" sebagai kekhasan daerah ini,lazimnya ditampung sebagai asas pada setiap Perda ataupun peraturan lainnya yang ditetapkan pemerintah provinsi Sumatera Barat, namun pengabaian formulasi syariat pada substansi norma, mengakibatkan filosofi itu seakan sebuah pepesan kosong.

Ketiga, realitas konflik tanah ulayat di Sumatera Barat, menyiratkanadasesuatuyang takberespadaformulasinormaataupada implementasiatau padakeduanya dan jika dibiarkan akan menimbulkan dilema hukum yang tak berkesudahan.

Berdasar uraian diatas, penelitian ini membatasi kajian pada persoalan pengaturan yang terkait erat dengan pemanfaatan tanah ulayat untuk kepentingan investasi, khususnya di bidang perkebunan, baik aturan itu dikeluarkan Pemerintah ataupun Pemerintah Daerah Provinsi Sumatera Barat. Dimaksud dengan pemanfaatan disini adalah pengelolaan tanah ulayat yang dilakukan oleh investor selaku pihak luar dari anggota persekutuan.Sedangkan untuk penelitian lapangan dicoba mencari akar utama konflik horizontal atas pemanfataan tanah ulayat bidang perkebunan di Nagari Tapan dan Lunang (setelah pemekaran menjadi 3 Kecamatan, tetapi tetap dalam satu wilayah KAN) Kabupaten Pesisir Selatan. Pemilihan lokasi berdasarkan tingkat potensial tanah ulayat pada satu sisi, namun pada sisi lain dengan belajar dari konflik yang terjadi, tumbuh rasa traumatis masyarakat hukum adat (MHA) setempat untuk bekerja sama dengan investor.Dengan demikian, permasalahannya adalah: 1 . Bagaimana pengaturan pemanfaatan tanah ulayat untuk kepentingan investasi? 2. Lantas bagaimana badan legislasi daerah Provinsi Sumatera Barat menyikapi dan mensyariatkannya? 3. Apa akar utama timbul konflik horizontal dalam pemanfaatan tanah ulayat di Sumatera Barat?

\section{METODE PENELITIAN.}

Metode Pendekatan yang digunakan dalam penelitian ini adalah gabungan antara yuridis normatif dengan yuridis empiris. Untuk menjawab permasalahan pertama dan kedua dilakukan penelitian yuridis normatif dengan bahan hukum primer (terutama peraturan perundang-undangan yang terkait erat dengan tanah ulayat) dan sekunder (literatur-literatur yang menjelaskan bahan hukum primer). Studi kepustakaan yang menghasilkan data sekunder itu, selanjutnya dinalisis secara kualitatif. Permasalahan ketiga dijawab melalui penelitian yuridis empiris dan dikhususkan pada konflik tanah ulayat di bidang perkebunan. Subyek penelitiannya adalah Lembaga Kerapatan Adat Nagari, Wali Nagari, tokoh-tokoh Agama dan anggota masyarakat hukum adat selaku penguasa hak ulayat pada 3 Kecamatan di Kabupaten Pesisir Selatan. Penentuan responden dan nara sumber melalui tehnik purposif sampling, dengan tehnik pengumpulan data berupa observasi tidak terlibat dan wawancara bebas. Pengecekan validitas data melalui tehnik triangulasi sumber untuk kemudian dianalisa secara kualitatif.

\section{HASIL PENELITIAN DAN ANALISIS \\ A. Dissinkronisasi Pengaturan Tanah ulayat Untuk Kepentingan Investasi.}




\section{a. Dilema antara Hak Menguasai Negara dan Hak milik Komunal.}

Hak menguasai Negara mencakup seluruh wilayah Indonesia, meliputi bumi, air dan ruang angkasa dengan segala sumber daya alamnya, baik pada wilayah yang belum ataupun telah dihaki oleh subyek hak. Hanya saja pada tanah yang telah dihaki oleh subyek hak, hak menguasai Negara itu bersifat pasif dan sebaliknya menjadi aktif atas tanah-tanah yang belum dihaki. Ide awal lahirnya hak menguasai negara muncul dari hubungan antara persekutuan masyarakat hukum adat dengan wilayahnya dan sekaligus untuk membedakannya dengan domein negara pada era kolonial. Dalam penjelasan umum Undang Undang Nomor 5 Tahun 1960 (UUPA), dinyatakan bahwa hak menguasai Negara ini," merupakan semacam hubungan hak ulayat yang diangkat pada tingkatan yang paling atas, yaitu pada tingkatan yang mengenai seluruh wilayah Negara”. Pada alinea keempat point II Penjelasan Umum UUPA itu ditegaskan lagi bahwa ; "hubungan itu adalah semacam hubungan hak ulayat, jadi bukan berarti hubungan milik". Artinya Negara bukanlah dikonsepsikan sebagai pemilik (eigenaar), karena jika demikian akan bertentangan dengan kesadaran hukum rakyat Indonesia dan azas dari pada Negara yang merdeka dan modern.

Persekutuan masyarakat hukum adat dengan penguasaan atas hak ulayatnya secara historis, jauh lebih dulu ada dibanding negara kesatuan Republik Indonesia. Setelah Indonesia resmi berdiri sebagai suatu Bangsa yang bersatu dan berdaulat, hak penguasaan atas tanah ulayat itulah yang kemudian dimodifikasi kedalam Hak menguasai Negara dengan cakupan ranah yang lebih luas; seluruh wilayah Republik Indonesia. Sekalipun dalam Peraturan Menteri Negara Agraria/Kepala Badan Pertanahan Nasional Nomor 5 Tahun 1999 Tentang Pedoman Penyelesaian Masalah Hak Ulayat Masyarakat Hukum Adat, hak penguasaan atas tanah ulayat itu tidak ditegaskan, namun dalam Surat Edaran Menteri Agraria Nomor 400-2626 Tahun 1999 tentang Penyampaian dan Penjelasan Peraturan Menteri Negara Agraria/Kepala Badan Pertanahan Nasional Nomor 5 Tahun 1999 dinyatakan bahwa Hak ulayat merupakan hak penguasaan yang tertinggi atas tanah dalam hukum adat, yang meliputi semua tanah yang termasuk dalam lingkungan suatu wilayah masyarakat hukum adat tertentu, yang merupakan tanah kepunyaan bersama (bukan milik) ${ }^{7}$ para warganya. Selanjutnya ditegaskan bahwa subyek hak ulayat tersebut adalah persekutuan masyarakat hukum adat terkait, baik persekutuan berdasarkan territorial, genealogis ataupun campuran. Bila mana seseorang tampil seakan-akan sebagai subyek hak ulayat, maka demikian bukanlah subyek hak, melainkan petugas masyarakat hukum adat yang memperoleh pelimpahan wewenang dari persekutuan masyarakat hukum adat. Demikian pula fungsi petugas Negara yang pada hakikatnya diberi pelimpahan wewenang dari semua warga atas hak menguasai negara.

Dalam skala mikro, hubungan antara persekutuan hukum desa, termasuk desa adat seperti Nagari (di Sumatera Barat) dengan tanah ulayat, berada dalam hubungan penguasaan desa/Nagari. Tegasnya, Desa/Nagari sebagai persekutuan hukum masyarakat adat mempunyai hak menguasai atas tanah ulayat, bukan merupakan hak kepemilikan. Inilah logika hukum dari UUPA.

Ditetapkannya Undang-Undang Nomor 6 Tahun 2014 tentang Desa, status hubungan penguasaan Desa/Nagari atas tanah ulayat menjadi ambigu, karena seakan lebih mengarah kepada 
hubungan kepemilikan. Pada Pasal 76 dinyatakan;

(1) Aset Desa dapat berupa tanah kas Desa, tanah ulayat, pasar Desa, pasar hewan, tambatan perahu, bangunan Desa, pelelangan ikan, pelelangan hasil pertanian, hutan milik Desa, mata air milik Desa, pemandian umum, dan aset lainnya milik Desa.

(2) Aset lainnya milik Desa sebagaimana dimaksud pada ayat (1) antara lain:

a) kekayaan Desa yang dibeli atau diperoleh atas beban Anggaran Pendapatan dan Belanja Negara, Anggaran Pendapatan dan Belanja Daerah, serta Anggaran Pendapatan dan Belanja Desa;

b) kekayaan Desa yang diperoleh dari hibah dan sumbangan atau yang sejenis dan \{..... $\}$.

Kalau Undang-Undang Nomor 6 Tahun 2014 tentang Desa tidak secara terang mengartikan hubungan antara subyek hak dengan tanah ulayat sebagai hubungan kepemilikan, maka dalam Peraturan Menteri Agraria dan Tata Ruang/ Kepala Badan Pertanahan Nasional No. 9 Tahun 2015 tentang Tata Cara Penetapan Hak Komunal atas Tanah Masyarakat Hukum Adat dan Masyarakat yang Berada dalam Kawasan Tertentu hal demikian dinyatakan secara tegas, bahkan istilah hak ulayat yang telah amat populis tidak disentuh sama sekali dengan langsung diganti sebagai hak milik komunal dan dijadikan obyek pendaftaran hak. Pasal 1 ayat (1) Peraturan Menteri Agraria dan Tata Ruang/ Kepala Badan Pertanahan Nasional No. 9 Tahun 2015 menyatakan;

Hak komunal adalah hak milik bersama atas tanah suatu masyarakat hukum adat atau hak milik bersama atas tanah yang diberikan kepada masyarakat yang berada dalam kawasan hutan atau perkebunan.

Jauh hari sebelum Permen ini ditetapkan, Maria S.W. Sumardjono menegaskan bahwa hubungan masyarakat hukum adat dengan tanah ulayat merupakan hubungan menguasai, bukan hubungan milik. ${ }^{8}$ Sebab itu tanah ulayat tidak menjadi obyek pendaftaran hak (Maria SW Soemarjono, 2005: 57) Tak urung, ketentuan Permen yang merubah status tanah ulayat mengundang komentar beliau; Permen 2015 ini menimbulkan kerancuan antara Hak ulayat dengan Hak Komunal. Disatu pihak pengaturan tentang hak Komunal menimbulkan ketidak pastian hukum, dipihak lain terjadi kekosongan hukum dalam pengaturan tanah ulayat dengan dicabutnya Permen No. 5 Tahun 1999. Bahkan ketentuan Permen diatas beliau nilai sebagai upaya pengeroposan terhadap UUPA dan kebijakan pertanahan jalan pintasseperti itu harus dihentikan. ${ }^{11}$ Dikaitkan dengan jenis tanah ulayat di Sumatera Barat, Kurnia Warman berpendapat:

Secara tehnis yuridis yang relevan disebut tanah ulayat hanyalah ulayat nagari, mungkin juga ulayat suku (pada kelarasan Bodi Caniago), sedangkan ulayat kaum lebih tepat dikatakan sebagai tanah milik komunal.

Beralihnya status hubungan dari hak penguasaan atas tanah ulayat kepada hubungan kepemilikan, akan membawa dampak serius dan resiko hukum kepada masyarakat hukum adat dan hal itu sangat tergantung pada karakter hukum adatnya. Di Sumatera Barat misalnya, berbeda 
dengan hak menguasai Nagari atas tanah ulayat yang dari semula tak perlu didaftarkan, dengan beralih sebagai hak kepemilikan dan dapat dilakukan sertifikasi atas tanah ulayat sebagai hak milik komunal atas nama anggota masyarakat hukum adat, pengurus koperasi atau unit Desa/ Nagari ataupun Kepala adat (lihat Pasal 13 ayat (3) Peraturan Menteri Agraria dan Tata Ruang/ Kepala Badan Pertanahan Nasional No. 9 Tahun 2015) dapat berakibat mudah hapusnya hak ulayat. Pada satu sisi benar, bahwa kepastian hak atas tanah ulayat akan terjamin dengan adanya sertifikasi, namun pada sisi lain akan mempermudah terjadinya peralihan hak ulayat, apalagi kalau subyek hak tertera tidak mempunyai tanggung jawab komunal.

Bila peralihan hak atas tanah ulayat itu terjadi, satu sendi utama adat matrilineal bearti telah runtuh. Dalam sistem kekerabatan matrilineal, pola hubungan mamak jo kamanakan (Mamak dengan kemenakan) sangat penting dan nyaris sejajar dengan hubungan orangtua dengan anak. Kedua hubungan itu saling melengkapi tanpa satu sama lain dapat dikalahkan. Ungkapan adat menyatakan "Anak dipangku, Kemenakan dibimbiang. Anak dipangku jo pancarian, kamanakan dibimbiang jo pusako

" (Nurdin Yakub, 1989: 10). Inti ungkapan menyatakan bahwa tanggung jawab seorang ayah di Minangkabau tidak terbatas kepada anak, melainkan juga terhadap kemenakan. Bila anak harus dibesarkan dengan harta pencaharian ayah, maka kemenakan dibesarkan dengan harta pusaka (termasuk tanah ulayat yang menjadi bagian dari harta pusaka). Dalam konteks pentingnya kemenakan itulah, menyebabkan harta pusaka diwariskan kepada kemenakan yang menjadi regenerasi clan. Kekhasan daerah seperti inilah yang diamanatkan konsititusi untuk dihormati, namun diabaikan Peraturan Menteri Agraria dan Tata Ruang/ Kepala Badan Pertanahan Nasional No. 9 Tahun 2015.

\section{b. Dampaknya Terhadap Pemberian hak atas Tanah Kepada Investor}

Tidaks eluruh bidang investasi memerlukan hak atas tanah sebagai landasan operasional dan hal itu sangat tergantung kepada obyek usaha. Diantara hak atas tanah yang banyak diperlukan itu adalah HakGuna Usaha(HGU), Hak Guna Bangunan (HGB) danHakPakai (HP). Untuk kepentingan pertanian (termasuk perkebunan), perikanan, peternakan, UUPAmenetapkan HGU hanya dapat diberikan atas tanah yang dikuasai langsung Negara (tanah Negara) untuk jangka waktu maksimal 35 tahun dan kemungkinan perpanjangan 25 tahundengantidakmenetapkan pembaruan hak (halini berbeda dengan ketentuanPasal 8 ayat (2), 11 ayat (1) PP. No. 40 Tahun 1996 danPasal 22 (1.a) UU No. 25 Tahun 2007 tentangPenanaman Modal yang memberi tenggang waktuHGU selama95 Tahun). Dengan demikian tidak memungkinkan terjadi HGU atas tanah ulayat, kecuali dengan menjadikannya sebagai tanah Negara lebih dahulu melaluipelepasan/ pencabutanhakdan seusaitenggangwaktu, takdapatkembali menjaditanahulayat. Menurut Kurnia Warman, ketentuan seperti itu jelas merugikan masyarakat hukum adat karenatanah ulayat mereka menjadipunah. ${ }^{14}$ Uniknya, Pasal 3 dan 4 ayat (2) Peraturan Menteri Agraria/Kepala Badan Pertanahan Nasional Nomor 5 Tahun 1999 membuka peluang untuk pemulihan hak ulayat ke bentuk semula. Dissinkronisasi vertikal inilah yang tampaknya seakan ingin dilerai oleh pemerintah 
dengan mencabut berlakunyaPeraturan Menteri Agraria/Kepala Badan Pertanahan Nasional Nomor 5 Tahun 1999 dan sekaligus mengesahkan Peraturan Menteri Agraria dan Tata Ruang/ Kepala Badan Pertanahan Nasional No. 9 Tahun 2015 yang dalam ketentuannya juga memuat pemanfaatan tanah ulayat oleh pihak ketiga (Pasal 14). Namun cara demikian tetap tidak menyelesaikan dilema HGU atas tanah ulayat karena hal itu tak disentuh dalam substansi aturan tersebut dan justru kian membuat runyam dengan merubah statusnya sebagai milik komunal. Jika pemerintah menghendaki produktifitas lahan/ tanah ulayat dikerjakan oleh pemilik sendiri, seperti yang diharuskan atas tanah ulayat yang berada dalam area perkebunan yang telah dilepaskan (Pasal 15 aturan diatas), maka tak perlu dibuka peluang kerjasama masyarakat hukum adat dengan pihak ketiga yang notabene memerlukan HGU untuk kepentingan usaha perkebunan.

Begitu pula denganpemberianHakPakai, yang hanyadapatdilakukanatastanah Negara, tanah Hak Pengelolaan atau pun tanah Hak Milik dan jika dipaksa kan atas tanah ulayat maka hal itu bertentangan dengan jiwa UUPA yang meletakkan posisi hak ulayat dalam hubungan penguasaan (bukan Hak Milik).

\section{B. Respon Provinsi Sumatera Barat : Menari Dengan Iringan Musik yang tak Padu}

Dengan otonomi daerah yang diperluas, memunculkan euforia bagi warga Minang umumnya untuk segera "mambangkik batang tarandam" (kembalinya Minang kepada pemerintahan nagari yang sudah lama hilang) pada euforia mana terkandung hasrat untuk kembali kepada adat yang bersendi syariat. Itu sebabnya didalam berbagai Perda yang ditetapkan badan legislasi Provinsi ini, hasrat tersebut dituangkan secara formal dengan diposisikan sebagai asas. Terkait pemanfaatan tanah ulayat, respon pemerintah daerah Propinsi Sumatera Barat baru tertuju kepada aturan terkait erat dengan tanah ulayat sebelum keluarnya Peraturan Menteri Agraria dan Tata Ruang/ Kepala Badan Pertanahan Nasional No. 9 Tahun 2015 dengan menetapkan dua peraturan berikut: 1) Perda No. 6 Tahun 2008 Tentang Tanah Ulayat dan Pemanfaatannya.

2) Pergub. No. 21 Tahun 2012 Tentang Pedoman Dan Tatacara Pemanfaatan Tanah Ulayat Untuk Penanaman Modal.

Pada kedua peraturan diatas, asas Adat basandi syarak, syarak basandi Kitabullah dicantumkan dengan tegas pada Pasal 2 (2) Perda jo Pasal 12 Pergub. Selanjutnya Pemerintah kabupaten dan Kota berwenang mengeluarkan Perda/aturan apapun lainnya yang diharap dapat bersinergi dengan Perda Propinsi.

Perda Propinsi No. 6 Tahun 2008 sistimatikanya terdiri dari IX Bab 17 Pasal, dan Pergub. No. 21 Tahun 2012 terdiri dari XI Bab dan 27 Pasal. Diantara substansinya memuat ketentuan bahwa dilarang penggunaan tanah ulayat oleh investor yang berakibat hapusnya hak ulayat dan ditekankan bahwa dalam pemanfaatannya haruslah melalui sistem kemitraan.

Menelaah substansi dari kedua peraturan diatas, badan legislasi daerah/Pemerintah Provinsi Sumatera Barat seakan menari dengan koreografi sendiri dibawah iringan musik yang tak padu. Kepincangan produk legislasi itu tampak dalam hal berikut: 


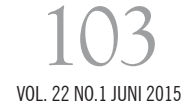

Pertama, dikotomi terhadap hak ulayat dengan menjadikan Hak Ulayat Nagari dalam konsepsi hak penguasaan, dan Hak Ulayat Suku dan Kaum sebagai Hak Milik Komunal. Ketiga jenis Hak ulayat tersebut dijadikan sebagai obyek pendaftaran hak. Tak hanya itu, Pengaturan Pasal 8 Perda diatas mengenai pemberian status HGU, Hak Pakai, atau Hak Pengelolaan kepada kelompok masyarakat adat selaku penguasa/pemilik atas tanah ulayat dalam pendaftaran tanah justru menimbulkan paradok internal antar Pasal. Pada satu sisi dengan pemberian hak atas tanah demikian, pelaksanaan atas hak ulayat oleh masyarakat adat dianggap terjadi diatas tanah negara ${ }^{15}$ atau tanah milik orang lain ${ }^{16}$, namun pada sisi lain diatur pengembalian hak ulayat kepada status semula usai tenggat waktu untuk pemanfaatan oleh investor berakhir sesuai ketentuan Pasal II Perda.

Selanjutnya, bila terjadi pemanfaatan atas tanah ulayat Nagari oleh investor, akan muncul HGU (yang dipunyai investor) atas HGU (yang dipunyai masyarakat adat) yang tak dijumpai legalisasinya. Sebaliknya dengan peralihan HGU kepada investor (misal dengan penjualan HGU) maka tidak akan memulihkan status hak ulayat kedalam bentuk awal setelah tenggang waktu HGU habis. Dikaitkan dengan Pasal 3 dan 4 ayat (2) Peraturan Menteri Agraria/Kepala Badan Pertanahan Nasional Nomor 5 Tahun $1999^{17}$ Tentang Pedoman Penyelesaian Masalah Hak Ulayat yang menetapkan bahwa wewenang pelaksanaan hak ulayat dari masyarakat hukum adat tidak dapat lagi dilakukan atas tanah ulayat yang telah dipunyai dengan suatu hak atas tanah sesuai UUPA oleh perseorangan ataupun badan hukum, ataupun atas hak ulayat yang telah dibebaskan, sejak saat Perda tanah ulayat ditetapkan. Dengan demikian, status tanah ulayat yang dapat dipulihkan kepada status semula, hanyalah atas tanah ulayat yang dimanfaatkan investor dengan hak atas tanah yang diperoleh setelah berlakunya Perda tentang pengaturan tanah ulayat. Sedangkan atas pemanfaatan tanah ulayat yang terjadi sebelum Perda dikeluarkan, tak dapat lagi dipulihkan. Kebijakan Pemda untuk menentukan pemulihan kembali atas semua tanah ulayat setelah tenggang waktu yang disepakati dengan investor habis, tampaknya merupakan suatu pilihan yang berangkat dari suatu phobia masyarakat matrilinial atas pelepasan tanah ulayat, terutama kepada non muslim yang mayoritas menjadi investor di daerah ini.

Kedua, hal lain yang perlu mendapat perhatian adalah, makna istilah " ganti rugi” dalam rumusan Pasal 8 (b) Pergub Provinsi Sumbar No. 21 Tahun 2012 (sebagai tindak lanjut Perda diatas) menjadi ambigu, karena pemberian ganti rugi berada dalam ranah pelepasan hak, baik sukarela ataupun terpaksa dan berakibat putusnya hubungan hukum antara subyek dengan obyek. Budi Harsono berpendapat:

bahwa pemberian ganti rugi yang lazimnya bernilai seimbang dengan nilai tanah di lokasi, telah mengakibatkan terjadi peralihan hak atas tanah karena telah terjadi pelepasan hak. Dengan pelepasan hak status tanah beralih menjadi tanah negara, hingga kemudian dapat diberikan kepada pihak yang membebaskannya dengan hak baru yang sesuai. ${ }^{18}$

Hal ini sangat berbeda dengan pemberianrekognisiyang tidak berakibat terjadinya peralihan hak atas tanah ulayat kepada pihak lain. Dikatakan Boedi Harsono :

Pemberian rekognisi bukanlah berarti, bahwa hak ulayat itu dilepaskan oleh masyarakat hukum adat yang 


\section{4 \\ JURNAL MEDIA HUKUM}

bersangkutan, tetapi justru merupakan suatu pengakuan adanya hak tersebut. ${ }^{19}$ Menurut Idrus Hakimy. Dt. Rajo Penghulu, lazimnya jumlah pembayaran recognisi yang di Sumatera Barat biasa disebut "bungo kayu, bungo ampiang " berkisar sekitar 10\% dari hasil yang diperoleh. Begitu izin penggunaan yang diberikan habis, maka berlaku adat: kabau tagak kubangan tingga (kerbau tegak (berdiri) kubangan tinggal). ${ }^{20}$ Maksudnya investor harus berangkat dan tanah kembali menjadi hak ulayat.

Pembayaran rekognisi sekitar 10\% lazimnya terjadi ketika potensi suatu tanah ulayat belum teruji, tapi ketika terbukti bahwa penggarapan tanah ulayat dapat jadi sumber ekonomi yang potensial berkat kemajuan tehnologi pertanian, maka nilai rekognisi dapat berubah. Antisipasi terhadap kondisi perubahan itu ditetapkan oleh ketentuan adat yang menyatakan "Sakali aia gadang, sakali tapian barubah". Ada beragam cara untuk menyikapi perubahan, diantaranya dengan melambungkan nilai rekognisi atau dengan bagi hasil yang lebih adil.

Ketiga, filosofi adat Minangkabau "adat basandi syarak, syarak basandi Kitabullah" sebagai kekhasan daerah ini, lazimnya ditampung sebagai asas pada setiap Perda ataupun peraturan lain yang dikeluarkan pemerintahan daerah di Sumatera Barat, namun dalam substansi tidak ada penjabaran selanjutnya dari filosofi itu, sehingga terkesan abstrak dan mengawang. Pola kemitraan berbagi tanah plasma dengan inti (30:70)seperti yang lazim dilakukan selama ini dan kesempatan untuk itu dibuka oleh ketentuan Pasal 10 Perda diatas dalam pemanfaatan tanah ulayat justru berseberangan dengan syariat (Hamzah Yakub, 1992: 272).

Bila berkaca kepada syariat, konsepsi syariat dalam transaksi muzaraah justru menghendaki bagi hasil dengan paroan (1:1) dan melarang pola bagi tanah. Hal ini dijelaskan oleh Rasul Muhammad SAW:

Dari Ibnu Umar, bahwasanya Rasulullah SAW, telah melakukan muamalah dengan penduduk Khaibar dengan separoh hasil yang keluar dari buah atau biji-bijian. (H.R. Bukhari dan Muslim). Pada satu riwayat bagi keduanya: "Mereka minta kepadanya (Nabi SAW) supaya Beliau membiarkan mereka dengannya (garapan), dengan syarat bahwa mereka akan menggarap tanah itu dengan mendapat separoh dari buahnya. Maka Rasullullah SAW berkata kepada mereka : "Kami perkenankan kalian padanya menurut syarat itu selama kami kehendaki”. Maka mereka tetap padanya hingga Umar keluarkan mereka dari padanya (Hamzah Yakub, 1992: 272).

Sedangkan mengenai larangan pola bagi tanahdi bidang muzaraah dijelaskan dalam suatu hadis :

Rafi' bin Khdij berkata, "Diantara Anshar yang paling banyak mempunyai tanah adalah kami, maka kami persewakan, sebagian tanah untuk kami dan sebagian untuk mereka yang mengerjakannya. Kadangkadang sebagian tanah itu berhasil baik dan yang lain tidak berhasil. Oleh karena itu, Rasullullah SAW melarang paroan dengan cara demikian.

Hal lainnya menyangkut kontrak yang sangat krusial, karena disanalah segala hak dan kewajiban para pihak ditetapkan. Terjadi/tidaknya wanprestasi oleh salah satu pihak, diukur dari materi kontrak dan dengan itu pula kerugian dapat ditentukan. Kontrak yang sebegitu penting seakan 
menjadi tak penting, ketika proses perizinan usaha dapat saja diterbitkan setelah terdapat bukti/ surat penyerahan tanah dari penguasa/pemilik, dan seterusnya persetujuan/izin prinsip, izin lokasi dan berujung pada keluarnya izin usaha. Berdasar izin usaha itulah, investor telah dapat memulai kinerjanya.

Kontrak yang semestinya berada pada deretan paling awal seakan dibiarkan tercecer di belakang untuk membuntuti proses yang terus berjalan, dan seakan tanpa akibat hukum, manakala tak pernah finis sampai tenggang waktu usaha berakhir. Peremehan terhadap kontrak untuk kepentingan proses perizinan usaha, pada hakikatnya merupakan pelecehan terhadap hak- hak masyarakat adat yang berada pada posisi tawar yang lemah. Proses demikian tak hanya dibuka Perda Provinsi No. 6 Tahun 2008, namun hal itu juga merupakan kesemrawutan aliran hukum dari hulu dalam ambisi memancing investasi.

Syariat memberi solusi lebih tepat dengan menghendaki kontrak para pihak berjalan didepan. Kontrak itulah hal primer dan berbagai dokumen lain hanyalah sekadar ikutannya. Dalam surat Al Baqarah ayat 282 Allah berfirman:

Artinya: Hai orang-orang yang beriman, bila kalian mengadakan perikatan tidak secara tunai untuk jangka waktu tertentu, maka hendaklah kalian menuliskannya (membuat perjanjian tertulis/kontrak).

Fakta di lapangan menunjukkan, bahwa ketiadaan kontrak menyebabkan posisi masyarakat adat selaku penguasa lahan menjadi sangat lemah dalam menuntut hak-haknya. Bagaimanapun bukti tulisan apalagi otentik jauh lebih meyakinkan digunakan sebagai alat bukti dibanding lisan.

\section{Sepenggal Konflik Tanah Ulayat di Sumatera Barat}

Realitas konflik tanah ulayat di Sumatera Barat, memang menyiratkan ada sesuatu yang tak beres pada formulasi norma ataupun pada implementasi.Konflik vertikal/horizontal yang tak kunjung usai terkait tanah ulayat di Ranah "Bundo Kanduang" ini dipicu berbagai sebab, diantaranya terjadi tumpang tindih lahan antara kebun garapan rakyat dengan lahan investor yang belum tentu berada pada lahan HGU semula, tidak diserahkannya kebun plasma yang menjadi hak MHA, dan ketiadaan kontrak ${ }^{25}$. Contoh konflik horizontal adalah yang sedang berlangsung di PN. Painan antara sekelompok tani Yenti Marni dan kawan ${ }^{26}$ berhadapan dengan PT. Sukses Jaya Wood selaku penggugat, dengan inti konflik merupakan perebutan atas sebagian lahan yang sama. Bermula dengan penyerahan tanah ulayat nagari dalam 2 tahapan dengan luas areal $2.400 \mathrm{Ha}$ oleh Ninik mamak Lunang kepada pihak pemerintah Kabupaten Pesisir Selatan untuk selanjutnya diserahkan kepada PT. Sukses Jaya Wood. Setahun kemudian pihak PT memohon perpanjangan izin lokasi untuk pemanfaatan tanah seluas 10.000 Ha dengan tawaran yang menggiurkan berdasar pola kemitraan bagi lahan seluas $6.400 \mathrm{Ha}$ untuk plasma, dan kebun inti cukup seluas $3.600 \mathrm{Ha}$. Tawaran menggiurkan itu berjalan mulus, dengan salah satu pertimbangan oleh Kantor Pertanahan Kabupaten adalah telah dilaksanakannya perolehan dan pembebasan tanah dengan baik pada 


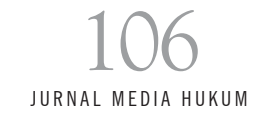

lahan 2.400 Ha semula. Bila telah dilaksanakan berarti pembebasan tanah tanpa kendala. Kalau kemudian muncul kasus dengan petani, maka besar kemungkinan terjadi justru pada lahan yang dipatok untuk pencapaian target $10.000 \mathrm{Ha}$ atau minimal pada target inti seluas $3.600 \mathrm{Ha}$. Dalam belantara hutan, tarik ulur luas HGU dapat saja terjadi, apalagi kalau batasan pemberian HGU cendrung kabur. Kuasa hukum PT dalam gugatannya bersikukuh bahwa lahan garapan petani walau telah diserahkan tersendiri oleh ninik mamak kepada petani, berada pada lahan HGU PT. Dari surat ninik mamak Lunang yang dilayangkan kepada bupati pada tahun 2006 untuk memohon peninjauan ulang atas wanprestasi pihak PT selaku investor, terungkap tidak adanya penggarapan lahan plasma oleh pihak PT. Rasionalisasi dapat dilakukan pihak investor untuk menghentikan kebun plasma, manakala area untuk perkebunan inti saja tidak mencukupi.Sampai kini surat yang dilayangkanseperti hilang bersama angin. Kasus serupa ditemukan Titin Fatimah dan Hengki Andora di Kabupaten lain di Sumatera Barat dengan pernyataan mereka:

Pemerintah Daerah sendiri berkeberatan untuk mendorong perusahaan untuk mengabulkan hak hak masyarakat adat, lantaran ketiadaan perjanjian tertulis untuk itu. Terkesan adanya keberpihakan pemerintah daerah kepada pihak perusahaan (Titin Fatimah dan Hengki ANdora, 2014: 20).

Ketiadaan kontrak berakibat sulit mengukur wan prestasi yang dilakukan debitur. Ditambah lagi dengan hubungan tidak langsung antar pihak terkait (lazimnya diperantarai pihak ketiga/ pejabat) memudahkan pihak lain/oknum pejabat ikut memanfaatkan peluang.

\section{SIMPULAN}

Berdasarkan uraian diatas, dapat diambil kesimpulan dari hasil penelitian sebagai berikut:

1. Terjadi dissinkronisasi vertikal/horizontal antar peraturan terkait tanah ulayat. Pada satu sisi UUPA menetapkan hubungan antara MHA dengan tanah ulayat sebagai hak penguasaan, sehingga tidak menjadi obyek pendaftaran hak, namun pada sisi lain, UU No. Tahun 2014 tentang Desa cendrung menganggap hubungan hukum itu berstatus kepemilikan dan hal demikian diperkuat dan sekaligus menjadi obyek pendaftaran hak oleh Peraturan Menteri Agraria dan Tata Ruang/ Kepala Badan Pertanahan Nasional No. 9 Tahun 2015. Kerancuan itu jelas mempengaruhi pemberian hak pada investor, peralihan dan pemulihan hak ulayat.

2. Terkait pemanfaatan tanah ulayat, Badan legislasi daerah Provinsi Sumatera Barat, mengeluarkan 2 aturan, yaitu Perda Provinsi Sumatera Barat No. 6 Tahun 2008 dan Pergub. No. 21 Tahun 2012. Bak menari ditengah iringan musik yang tak padu dan dibumbui semangat religius untuk mewujudkan filosofi adat, ternyata produk legislasi terkait tanah ulayat di Provinsi Sumatera Barat, membedakan antara hak ulayat Nagari sebagai hak penguasaan dengan hak ulayat Suku dan ulayat Kaum sebagai hak milik komunal dan semuanya menjadi obyek pendaftaran hak. HGU, Hak Pengelolaan ataupun Hak Pakai yang dapat diberikan kepada penguasa hak ulayat Nagari sesuai aturan Perda Provinsi Sumatera Barat, justru memberi kesan hak ulayat telah menjadi tanah Negara atau kepemilikannya berada pada pihak lain. 
Dengan diatur pemulihan kembali atas hak ulayat, melengkapi ketimpangan adanya paradok antar Pasal, sehingga sulit untuk disebut sebagai Perda yang ideal, apalagi sebagai Perda yang mensyariat karena nilai-nilai syariat pada unsur penting terabaikan.

3. konflik horizontal yang tak kunjung usai terkait tanah ulayat di Ranah "Bundo Kanduang" ini dipicu berbagai sebab, akar utamanya adalah tumpang tindih lahan antara kebun garapan rakyat dengan lahan investor, tidak diserahkan lahan plasma dan tak dibuatnya kontrak secara jelas oleh para pihak sehingga sulit mengukur wan prestasi. Uniknya dalam pengurusan izin usaha, kontrak antara ninik mamak dengan investor tidak dianggap sebagai elemen primer sebab dengan bukti surat penyerahan hak atas tanah ulayat oleh MHAproses perizinan usaha sudah dapat dirampungkan. Demikian pula dengan hubungan tidak langsung antar pihak terkait, memudahkan pihak lain/oknum pejabat ikut memanfaatkan peluang.

\section{CATATAN AKHIR}

1 Lihat Soeroyo Wignyodipuro, 1983, Pengantar dan Asas-asas Hukum Adat, Gunung Agung, Jakarta, hlm. 197.

2 Soetandyo Wignjsoebroto, dari Hukum Kolonial ke Hukum Nasional, PT. Raja Grafindo Persada, Jakarta, 1995, Hal. 90

3 www.pancanaka.org/index.php?option=com_content\&veiw=article\&id=200:tinggi/konfliktanah-ulayat-di-sumbar\& catid=85\&ltemid=222, diaksestanggal9 Mei2014

4 Lihat, Arfi Bambani Amri, Keluar dari Sengketa Ulayat, tersedia pada www.hariansinggalang.co.id/ keluar-dari-sengketa-ulayat/, diakses tanggal 9 Mei 2014

5 Mengenai benturan antara berbagai peraturan perundang-undangan yang menyangkut pengaturan sumber daya alam (termasukhakulayat)diungkapkan jugaolehMaria Soemarjono, dkk,2011,PengaturanSumberDayaAlamdiIndonesia,GajahMada UniversityPress, hlm.iv, dan Warman, Kurnia,2010, Hukum Agraria dalam masyarakatmajemuk, Dinamikainteraksihukum adat dan hukum Negara di Sumatera Barat, KITLV, Jakarta, hlm.4.

6 Lihat Penjelasan Umum UUPA point II. 2.

7 Penegasan dari penulis.

8 Maria SW. Soemarjono, 2005, Kebijakan Pertanahan, antara Regulasidan Implementasi, Kompas Media Nusantara, Jakarta, hlm. 57

9 Lihat, Ibid, hlm. 71.

10 LengkapnyapadaKompas 6 Juli 2015.

11 Lengkapnyapada, Kompas 25 September 2015.

12 KurniaWarman, 2006, GanggamBauntuakMenjadiHakMilik, Andalas University Press, Padang. Hlm. 59.

13 Ungkapan ini sangat populer dan banyak diungkap para penulis tentang adat Minangkabau, diantaranya, Nurdin Yakub, 1989, Minangkabau Tanah Pusako 2, Pustaka Indonesia, Bukittinggi, hlm 10 dan Idrus hakimy Dt. RajoPenghulu, 1997, Rangkaian Mustika Adat Basan di Syarak 


\section{8}

di Minangkabau, Remaja Rosda Karya, Bandung, hlm. 207.

14 LihatKurniaWarman, PolahubunganHukumdalamPemanfaatan Tanah Ulayat di Sumatera Barat, JurnalMimbarHukum, Vol. 26 No. 3, 2014. FH.UGM, hlm. 371.

15 HGU dan Hak Pengelolaan hanya dapat diberikan atas tanah Negara.

16 Hak Pakai hanya dapat diberikan atas tanah Negara ataupun tanah milik orang lain.

17 SaatPerdaditetapkan, ketentuaninimasihberlakudandijadikanacuanPerda.

18 Boedi Harsono, 1974, Undang-Undang Pokok Agraria, Sejarah Penyusunan dan Pelaksanaannya Jakarta.jilid 2, hlm. 216

19 Lihat, Boedi Harsono, 1974, Undang-Undang Pokok Agararia, Sejarah Penyusunan dan Pelaksanaannya, Jilid 1, Djambatan, Jakarta, hlm. 168..

20 Lihat, Idrus Hakimy Dt Rajo Penghulu, op cit, hlm. 209.

21 Artinyasekali air (sungai) membesar, sekali (pula) tepian sungai beranjak. Maksudnya dinamika sosialikut merubah sistem.

22 lihatHamzah Yakub, 1992, Kode Etik Dagang Menurut Islam, CV. Diponegoro, Bandung, hlm. 272 dan Sulaiman Rasyid, 2012, Fiqh Islam, Sinar Baru Algesindo, Bandung, hlm. 302.

23 Hamzah Yakub, loc cit.

24 Sulaiman Rasyid, loccit, hlm. 302.

25 Wawancara dengan Ketua KAN Lunang, tgl 27 Okt 2014, KAN Tapan, tgl.23 Septemb, 2014, HattaLatif (tokoh Masyarakat), 25 Septemb. 2014, Zulkardi (walinagari Bukit Buai) tgl.26 Septemb.2014, dan Syahbunan Zaini (tokoh Agama) tgl 20-26 Septemb dan awal November 2014.

26 Wawancara dengan Yantimarni dkk, tgl.26 Septemb.2014, pada saat mana diperoleh juga berbagai dokumen terkait.

27 Lihat Titin Fatimah, Hengki Andora, 2014, Jurnal Ilmu Hukum FH. UNRI, vol 4, hlm 20.

\section{DAFTAR PUSTAKA}

Hakimy, Idrus, Dt. Rajo Penghulu. 1997, Rangkaian Mustika Adat Basandi Syarak di Minangkabau, Remaja Rosda Karya, Bandung.

Hamzah Yakub, 1992, Kode Etik Dagang Menurut Islam, CV. Diponegoro, Bandung,

Harsono, Boedi, 1974, UUPA, Sejarah Penyusunan dan Pelaksanaannya, jilid.I,II, Jembatan, Jakarta.

Rasyid, Sulaiman, 2012, Fiqh Islam, Sinar Baru Algesindo, Bandung.

Sumardjono, Maria SW, et al,2011, Pengaturan Sumber Daya Alam di Indonesia. Antara yang Tersurat dan Tersirat, Gadjah Mada University Press, Yogyakarta.

2005, Kebijakan Pertanahan, antara Regulasi dan Implementasi, Penerbit Buku Kompas, Jakarta.

Warman, Kurnia, 2010, Hukum Agraria dalam masyarakat majemuk, Dinamika interaksi hukum adat dan hukum Negara di Sumatera Barat, KITLV, Jakarta.

2006, Ganggam Bauntuak Menjadi Hak Milik, Penyimpangan Konversi Hak Tanah di Sumatera Barat, Andalas University Press. Padang. 


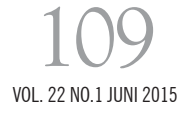

Wignyodipuro, Soeroyo, 1983, Pengantar dan Asas-asas Hukum Adat, Gunung Agung, Jakarta.

Wignyosoebroto, Soetandyo, 1995, Dari Hukum Kolonial ke Hukum Nasional, Dinamika Sosial Politik dalam Perkembangan Hukum Indonesia, Raja Grafindo Persada, Jakarta.

Yakub, Nurdin. B. Dt. 1990, Minangkabau Tanah Pusaka, Tambo Minangkabau Buku Kedua, Pustaka Indonesia, Bukittinggi.

Afifah Kusumadara, 2013, Perkembangan Hak Negara Atas Tanah: Hak Menguasai Atau Hak Memiliki?, Jurnal Media Hukum, Vol. 20 No. 2

Warman, Kurnia, AndoraHengki, 2014, Pola Hubungan hukum dalam Pemanfaatan Tanah ulayat di Sumatera Barat, Mimbar Hukum, FH. UGM, Volume 26.

Titin Fatimah, Hengki Andora, Pola Penyelesaian Sengketa Tanah Ulayat di Sumatera Barat (Sengketa antara Masyarakat dengan Investor, Jurnal Hukum, FH. UNRI, volume 4.

Maria SW Sumardjono, 2015, UUPA Setelah 55 Tahun, Harian Kompas, 25 September 2015

2015, Ihwal Hak Komunal atas Tanah, Harian Kompas, 6 Juli 2015

Arfi Bambani Amri, Keluar dari Sengketa Ulayat, tersedia pada www.hariansinggalang.co.id/ keluar-dari-sengketa-ulayat/, diakses tanggal 9 Mei 2014.

NurulFirmansyah, TingginyaKonflik Tanah ulayat di Sumatera Barat,www.pancanaka.org/ index.php?option=com_content\&veiw=article\&id=200:tinggi/konflik-tanah-ulayat-disumbar\&catid $=85 \&$ ltemid $=222$, diaksestanggal9 Mei2014

Undang-UndangNomor 5 Tahun 1960 tentangPeraturanDasarPokok-PokokAgraria.

Undang-UndangNomor 25 Tahun 2007 tentang Penanaman Modal.

Undang-UndangNomor 6Tahun2014 tentang Desa.

Undang-Undang Nomor 39 Tahun 2014 Tentang Perkebunan.

Peraturan Pemerintah Nomor 40 Tahun 1996 tentang Hak Guna Usaha, Hak Guna Bangunan dan Hak Pakai atas Tanah.

Peraturan Menteri Negara Agraria/Kepala Badan Pertanahan Nasional Nomor 5 Tahun 1999 Tentang Pedoman Penyelesaian Masalah Hak Ulayat.

Peraturan Menteri Dalam Negeri Nomor 52 tahun 2014 Tentang Pedoman pengakuan dan perlindungan masyarakat hukum adat.

Peraturan Menteri Agraria dan Tata Ruang/ Kepala Badan Pertanahan Nasional No. 9 Tahun 2015 tentang Tata Cara Penetapan Hak Komunal atas Tanah Masyarakat Hukum Adat dan Masyarakat yang Berada dalam Kawasan Tertentu.

Peraturan Daerah Propinsi Sumatera Barat Nomor 6 Tahun 2008 tentang Tanah Ulayat dan Pemanfaatannya.

Peraturan Gubernur Nomor 21 Tahun 2012 tentang Pedoman Dan Tatacara Pemanfaatan Tanah Ulayat Untuk Penanaman Modal. 